\title{
HOW DOES WORK ENVIRONMENT INFLUENCE PRODUCTIVITY DURING COVID-19 PANDEMICS? A CASE STUDY IN IPB UNIVERSITY
}

\author{
Ghassani Adisa Nuramalina*) and Eko Ruddy Cahyadi")1 \\ *) Department of Management, Faculty of Economics and Management, IPB University \\ Jl. Agatis, IPB Darmaga Campus, Bogor 16680, Indonesia
}

\begin{abstract}
Coronavirus was declared as a pandemic by WHO on March 11, 2020. Since that decision, Work From Home (WFH) policy has also begun to be applied to all offices, including educational institutions in Indonesia. IPB, as one of the institutions that also implements the WFH policy, still has to maintain the productivity of its staff although their work environment has been changed. This research aims to analyze the effect of the work environment, both physical and non-physical on the productivity of IPB's staff in normal work situations and WFH situations. The respondents were obtained by distributing questionnaires online via google form. The data analysis technique used is descriptive analysis, Wilcoxon test, and SEM PLS. The results show that in normal and WFH work situations, physical work environment and non- physical work environment have a positive and significant effect on the productivity of IPB's staff. It means that the productivity of IPB's staff can be increased if a good physical and non- physical work environment is available, which suitable for the working condition both during normal and WFH situations.
\end{abstract}

Keywords: educational institution, SEM-PLS, supporting staff, policy, work from home

\begin{abstract}
Abstrak: Virus Corona ditetapkan sebagai pandemi oleh WHO pada tanggal 11 Maret 2020. Sejak penetapan tersebut, maka kebijakan Work From Home (WFH) juga mulai diterapkan pada seluruh perkantoran, tidak terkecuali pada institusi pendidikan di Indonesia. IPB, sebagai salah satu perguruan tinggi yang juga menerapkan sistem WFH, harus tetap mempertahakan produktivitas tenaga kependidikannya walaupun terjadi perubahan situasi kerja. Penelitian ini bertujuan untuk menganalisis pengaruh lingkungan kerja, baik fisik maupun non fisik terhadap produktivitas kerja tenaga kependidikan IPB pada situasi kerja normal dan Work From Home. Responden pada penelitian diperoleh dengan menyebarkan kuesioner secara online melalui google form. Teknik analisis data yang digunakan adalah analisis deskriptif, uji wilcoxon dan SEM PLS. Hasil penelitian menunjukkan bahwa pada situasi kerja normal maupun WFH, variabel lingkungan kerja fisik dan lingkungan kerja non fisik memiliki pengaruh yang positif dan signifikan terhadap produktivitas kerja tenaga kependidikan IPB. Hal ini menunjukkan bahwa produktivitas kerja tenaga kependidikan dapat ditingkatkan jika tersedia lingkungan kerja fisik dan lingkungan kerja non fiisik yang baik, yaitu sesuai dengan kondisi kerja baik pada saat kerja normal maupun WFH.
\end{abstract}

Kata kunci: institusi pendidikan, SEM-PLS, staf pendukung, kebijakan, work from home

\footnotetext{
${ }^{1}$ Corresponding author:

Email: ekocahyadi@apps.ipb.ac.id
} 


\section{INTRODUCTION}

The Coronavirus was declared as a pandemic by the World Health Organization or WHO on March 11, 2020. Since this determination, the Work From Home (WFH) system has also been implemented in Indonesia. The WFH system is a concept where employees can do their work from home (Kemdikbud, 2020). The application of this system is carried out in all offices, including educational institutions. Based on data from the Ministry of Education and Culture (2020), the WFH system is also implemented in educational institutions to maintain the health and safety for both students, educators, and supporting staff during the Covid-19 pandemic.

As one of Indonesia's universities, the Bogor Agricultural Institute (IPB) has also implemented WFH policies during the Covid-19 pandemic. Based on PP RI No. 66 of 2013 concerning the Statute of the Bogor Agricultural Institute, IPB's human resources consist of educators and supporting staff with employment status which are divided into Civil Servants (PNS), permanent employees, and contracts. According to Law No. 20 of 2003 concerning Article 39 of the national education system, educators are supporting staff who are qualified as teachers, lecturers, counselors, facilitators, and other designations that are in accordance with their field of specialization and participate in education delivery. Meanwhile, supporting staff are members of society who are devoted and appointed to support the implementation of education. In addition to their role as supporting the implementation of the tridharma of higher education, supporting staff have an important role in the implementation of administration, management, development, supervision and technical services in supporting units (Law No. 20 of 2003).

Based on data from the Ministry of Manpower of the Republic of Indonesia, the productivity of Indonesian workers needs special attention. According to the World Competitive Index 2019, Indonesia's ranking has dropped from 45 to 50 . One of the causes of this is because human resources in Indonesia are less productive (Kemnaker, 2020). According to data from the Ministry of Education and Culture (2019), human resource development has also become a serious concern for the government, especially for the supporting staff. This is because not many people are aware of the strategic role of supporting staff for the sucsess of educational institution. Based on Human Resources data IPB in 2020, it is known that IPB has a supporting staff of 2,303 people who are divided into several work units. This shows that with IPB must be able to improve the quality of its supporting staff so that they become productive human resources.

The work environment is one of the factors that affect employee productivity at work. Based on the theory of Siagian (2014), a conducive work environment will create enthusiasm for work so that it will increase employee performance and work productivity. Research shows that the implementation of the WFH system has an influence on employee work productivity. This is due to differences in the work environment at home and at the office. According to Mustajab et al. (2020), WFH can reduce employee productivity. This reduce work productivity is due to the fact that the facilities available at home are not as complete as the work facilities in the office. However, it is different from the research conducted by Dokery and Bawa (2020) that WFH allows employees to devote more time to work more productively if employees set clear boundaries of time and space for work and non-work activities while at home.

The scope of this research focuses on the physical work environment, non-physical work environment and work productivity of IPB's supporting staff in normal work situations and working from home. Respondent were limited to supporting staff with civil servant, permanent and contract status at IPB who worked at home during the Covid-19 pandemic. The work environment studied uses Siagian (2014) theory beside work productivity, uses the theory of Simamoran (2004) dan Sutrisno (2009). This research aims to analyze the perceptions of supporting staffs regarding the physical and the nonphysical work environments during work from home. Besides, the study is also analyzes the effect of work environment on productivity both in normal situation before pandemic and WFH during the pandemic. The novelty of this study are incorporating dynamics of work environment during the pandemics and its effect on productivity. This contribute to the literature on how and to what extend work environment affect productivity. 


\section{METHODS}

This research was conducted at the Bogor Agricultural Institute in April-June 2020. The questionnaire filled out by supporting staff and distributed online via google form. The rquestionnaire's link was distributed to the head of each IPB's supporting staff unit. Furthermore, the head from each work unit disseminate it to the supporting staff. Sampling method that used is probability sampling with simple random sampling technique. There were 120 respondents with dominant characteristics: male gender, age 36-45 years, married status, latest education undergraduate, with civil servant status in Category III and length of work $\geq 21$ years. In this study, the type of data used was quantitative data and the data source was obtained from primary data. The data processing and analysis methods used are validity test, reliability test, descriptive analysis, normality test, Wilcoxon test and Structural Equation Modeling through Partial Least Square (SEM PLS). The tools used to analyze software IBM SPSSversion 19 and smart PLS 3.

Our research framework is presented in Figure 1. The Work from Home policy during the pandemic was also applied to the Bogor Agricultural Institute and had an impact on human resources, one of them was the supporting staff. Efforts to increase work productivity can be done by creating a good work environment for employees. The work environment in this study is discussed using Siagian (2014) theory, while the work productivity in this study uses the Simamora (2004) theory combined with Sutrisno's (2009) theory. Descriptive analysis is conducted to test the perceptions of education personnel about physical and non-physical work environments and good work productivity. in normal work situations and WFH. After that the Wilcoxon test is carried out to test different indicators of the physical work environment, non-physical work environment and work productivity. Furthermore, SEM-PLS analysis was carried out to test the effect of the work environment on the work productivity of the educational workforce in normal work situations and WFH so that managerial implications were generated as a form of input or suggestions from the research results to IPB.

\section{Hypothesis Development}

The relationship of the physical work environment towards work productivity in normal work situation

The physical work environment is a physical form that is around the workplace and can affect employees (Siagian, 2014). According to research conducted by Manikottama et al. (2019), bad work environment will decrease employee work productivity. The availability of a good physical work environment according to the company operational standards can affect the work productivity of employees (Desmonda,2016). a healthy workspacecaninfluencebothwell-beingandproductivity (Hansen, 2017). Beside that, space components like office furniture such as desks chairs, shelves, etc., have a specified part to play in the productivity of the employees and the suitable functioning of any office (Al-omari and Okasheh, 2017). Good working conditions will provide comfort in working so that it can increase employee productivity (Atmaja and Puspitawati, 2018). In addition, good physical working environment inspires workers to spend more time in the offices, and other negative attitude like lateness to work and un necessarily absent will be drastically reduced so that it will increase employee work productivity (Ebenezer and Shimawua, 2017). H1.1: Physical work environment in normal work situations has a significant effect on work productivity in normal work situations.

\section{The relationship of non-physical work environments towards work productivity in normal work situations}

According to Siagian (2014) theory, a non-physical work environment is a harmonious work relationship between colleagues and between superiors and employees. Based on the research conducted by Septiani (2016), non-physical work environments have a positive effect on employee work productivity. Harmonious relationships with coworkers without any disputes between co-workers are one of the factors that can influence employees to stay in the organization. Moreover, cooperation between employees must be maintained properly, because it will affect the work done. If the cooperation between employees is well established, employees can complete work effectively and efficiently. In addition, good communication network between employees will attract, keep, and motivate its workforce for healthy living and improved 
work productivity (Joseph, 2016). H1.2: Non-physical work environment in normal work situations has a significant effect on work productivity in normal work situations.

The relationship of the physical work environment towards work productivity in the WFH situation

According to research conducted by Siddharta and Malika (2016) Employee who work from home, work in suitable work and they save the travel time. Beside that, according to Dokery and Bawa (2020), WFH allows employees to devote more time to working more productively if employees clearly define time and space boundaries for work or non-work activities while at home. The availability of a special workspace while working at home, complete equipment and facilities for doing WFH is very supportive and can increase employee productivity (Miller, 2016). According to research by Kramer (2020), The employees' productivity are dependent on a work environment that may be continuously threatened in the future. This also supported by research which states that the availability of adequate technology as a resource enables workers to be more productive, because it makes it easier and faster for employees to share and communicate information to their colleagues during WFH situation (Amador 2016). H2.1: The physical work environment in the work from home situation has a significant effect on work productivity in the work from home situation

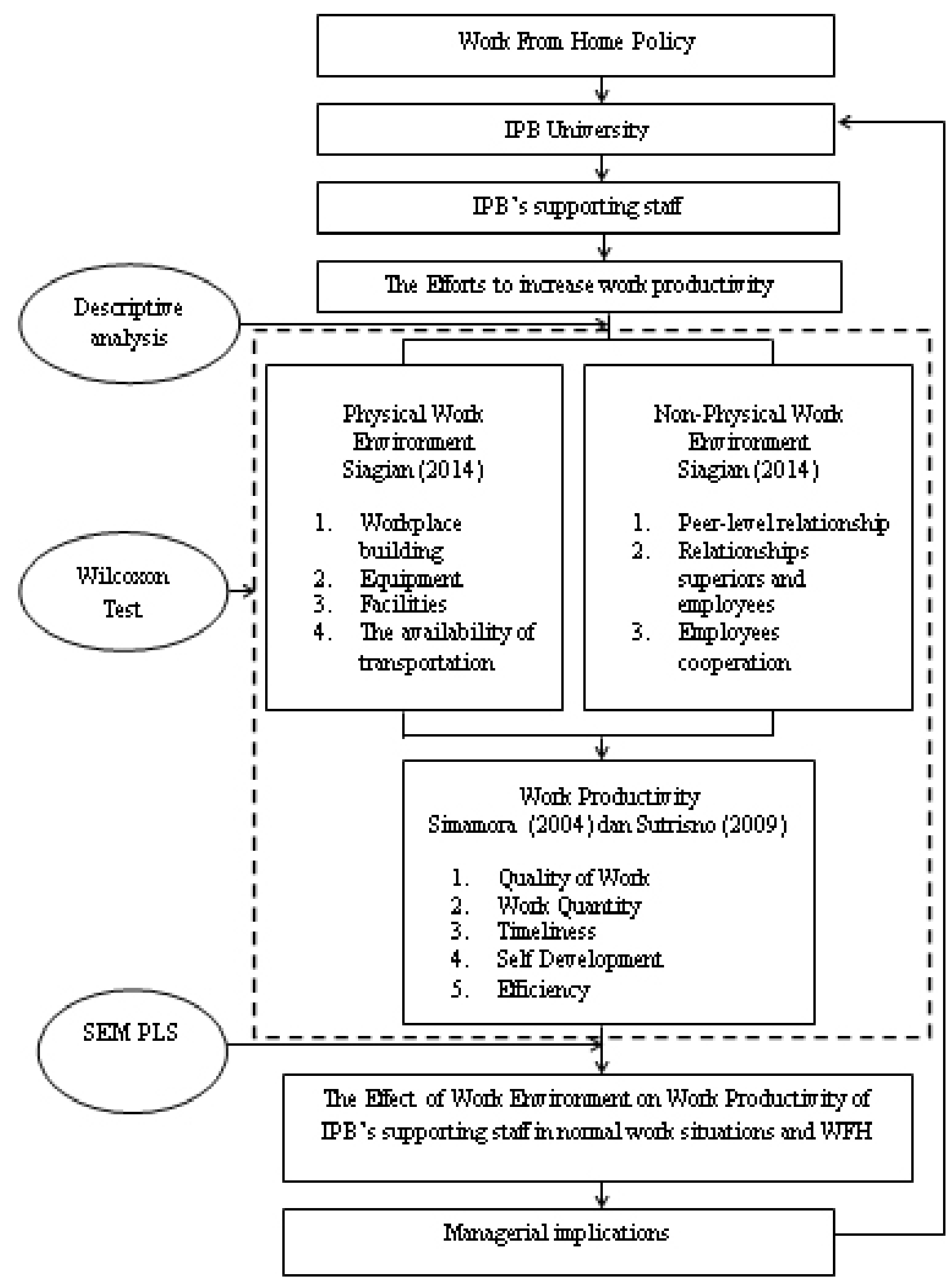

Figure 1. Research framework 
The relationship of the non-physical work environment in the WFH situation to work productivity in the WFH situation

According to research conducted by Bosua et. al (2013) non-physical work environment affects work productivity. This is because the non-physical work environment that exists during WFH is different from work from the office. Aspect that affects work productivity while working from home is trust between employees and between managers and employees. Beside that, The availability of flexible work arrangement while working at home helps employees building positive work attitudes thus eliminating negative emotions toward work which result in employee staying in the company (Gunaprasida and Wibowo, 2019). Built-in flexibility also reduces employee burnout due to overload. Flexibility means employees can take a break when they need it without incurring the wrath of a manager (Heathfield, 2019). In addition, according to research by Kossek and Thompson (2016), direct managers may find it more difficult to assess employee productivity in terms of output and not 'face time' when employees work from home as well as to motivate workers. Therefore, maintaining a harmonious relationship between employees and superiors is important while working from home. H2.2: The non-physical work environment in the work from home situation has a significant effect on work productivity in the work from home situation

\section{RESULTS}

This research questionnaire consist of two work situations, namely the normal work situation and the WFH situation. Before conducting the research, the instrument test was conducted, namely the validity and reliability tests of 30 respondents. . The validity test in this study was carried out with a significant level of $5 \%$ or 0.050 , so the $r$ table was 0.361 . The results of the validity test state that all indicators or statements used have the calculated $r$ value greater than 0.361 or declared valid. Furthermore, the reliability test was carried out with the Cronbach alpha $(\alpha)$ statistical test. A construct or variable is said to be reliable if the cronbach alpha $(\alpha)$ value is $>0.600$ (Ghozali 2014). In this study, the results of the reliability test of all variables used were declared reliable or had a Cronbach alpha $(\alpha)$ value $>0.600$.
The results of the descriptive analysis show that the physical and non-physical work environments at IPB are good. Whereas in the WFH situation, the results of the descriptive analysis show that the perceptions of supporting staff towards the physical work environment are quite good and the non-physical work environment is good. Testing differences in indicators of equipment completeness and condition, harmonious work relationships and work productivity of IPB's supporting staff in normal and WFH work situations were carried out using the Wilcoxon test. The results show that there are significant decrease in the indicators of completeness and condition of work equipment, as well as in all indicators of supporting staff productivity. It is because the work equipment availableathome is not as complete as that available at IPB. In addition, there was an insignificant decrease in the indicator of harmonious work relations among supporting staff that happened due to miscommunication during work. Furthermode testing the influence of the physical and non-physical work environtment in both normal and WFH work situations was carried out using the structural Equation Modelling Partial Least Square (SEM PLS) method. SEM PLS analysis was carried out in several evaluations, as follows:

\section{Measurement Model (Outer Model)}

Themeasurementmodel(outermodel)describestherelationship between latent variables and their respective indicators. The measurement model is used to test construct validity and instrument reliability (Ghozali, 2014). The convergent validity test can be seen from the loading factor value of each indicator and the Average Variance Extracted (AVE). The indicator is declared valid if it has a loading factor value above 0.700 (Ghozali, 2014). Furthermore, the AVE value of each construct must be above 0.500 . In a normal work situation there are 15 indicators with a loading factor value of less than 0.700 . These indicators include BTK1 (uniqueness of work buildings), BTK3 (health of work buildings), PRL1 (fulfillment of work equipment needs), FSL1 (availability of toilet facilities), FSL2 (availability of worship facilities), FSL3 (availability of facilities to relieve fatigue), FSL5 (Availability of supporting facilities), TRP1 (Easy access to transportation facilities at IPB), KAK1 (Employee sensitivity in helping other employees), KAK2 (Contribution of team members in collaboration), KNT3a (Fulfillment of work quantity exceeds the standard), WKT1a (Accuracy of working hours ), WKT2a (Ability to complete tasks), WKT3a (Time management ability), and EFI2a (Ability to use resources effectively). The following is the outer model along with the loading factor value after dropping which can be seen in Figure 2. 
Unlike the normal work situation, in the WFH situation there are 11 indicators with a loading factor value of less than 0.700 . These indicators are PRL4 (Condition of working equipment at home), FSL6 (Availability of internet network), TRP3 (Availability of special transportation from IPB), TRP4 (Availability of public transportation during WFH), HRS3 (Harmony of working relationships during WFH), HRS4 (Smooth communication during WFH),
KAK3 (Responsibilities of team members during WFH), KAK4 (Coordination of team work during WFH), KNT3b (Fulfillment of work quantity exceeding standards), WKT1b (Accuracy of working hours), and WKT2b (Ability to complete tasks). The following is the outer model along with the loading factor value after dropping which can be seen in Figure 3 and the Average Variance Extracted (AVE) value before and after dropping in normal work situations and WFH which can be seen in Table 1

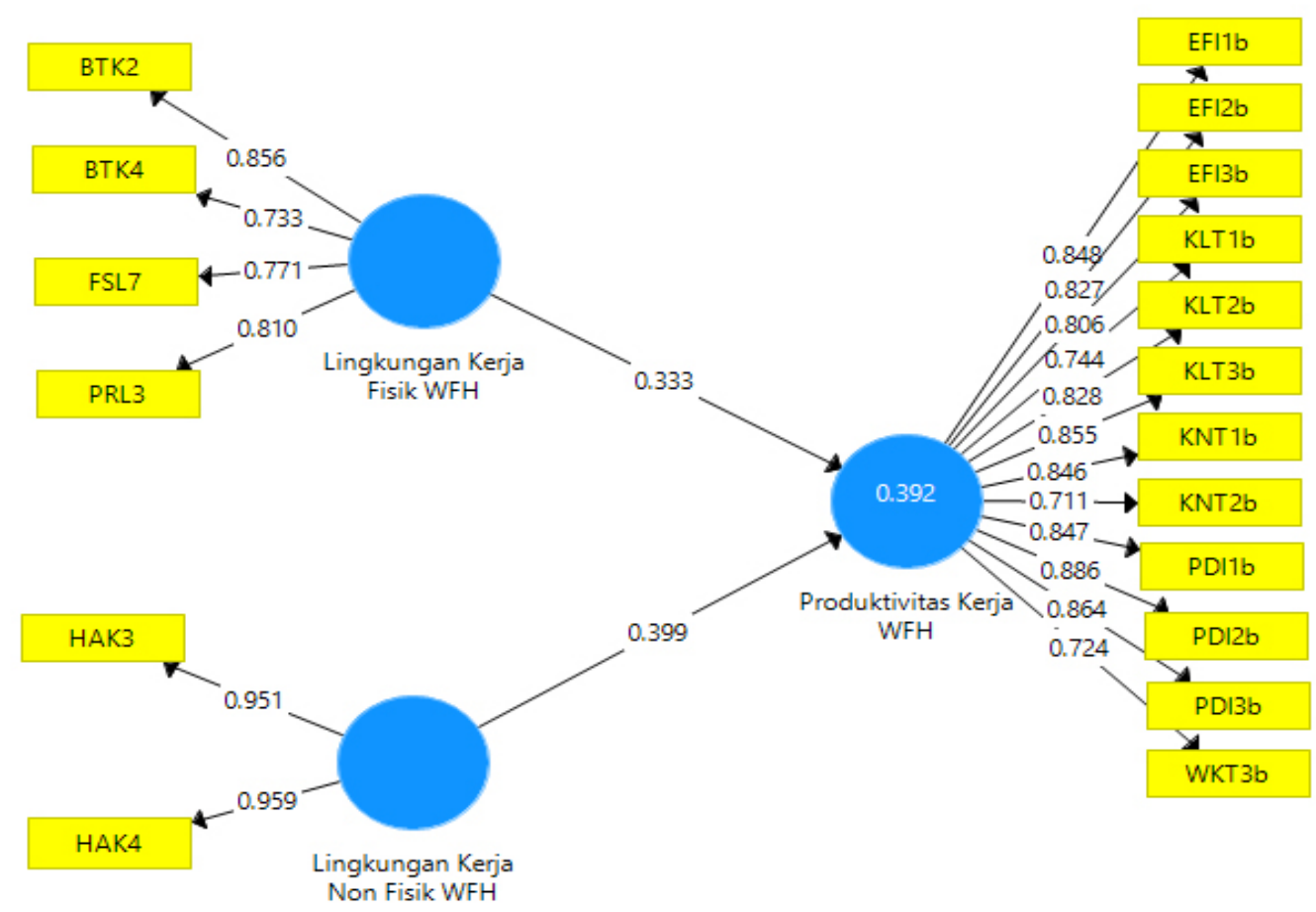

Figure 2. Outer model under normal work situation after dropping

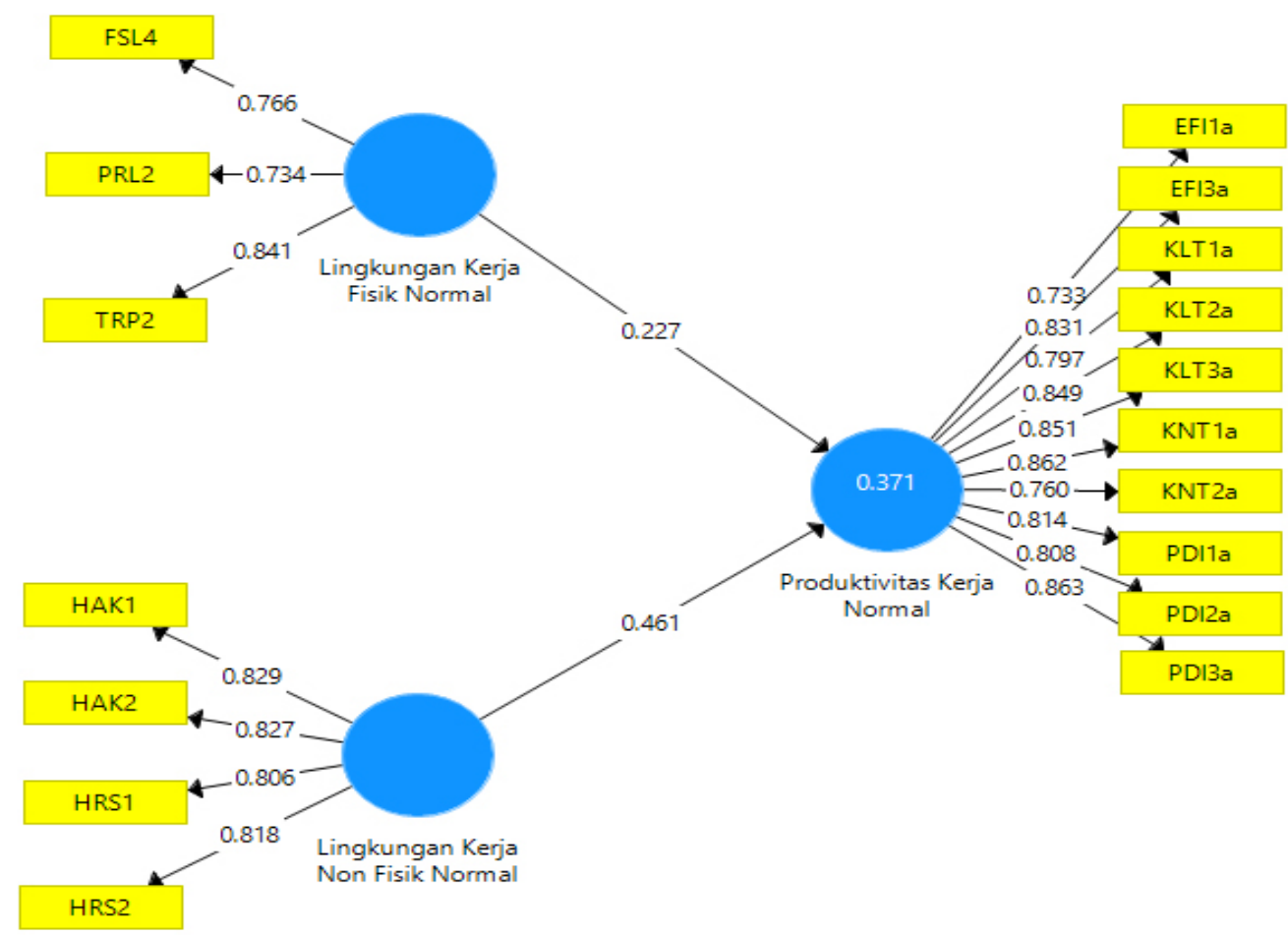

Figure 3. Outer model in the WFH situation after dropping 
Based on Table 1, it is known that there are 3 variables with AVE values before dropping that are less than 0.500. Furthermore after dropping and recalculating, the AVE value is above 0.500 . Based on this, the model is said to be good. Moreover the discriminant validity test can be seen from the cross loading value of each indicator to determine whether the construct has adequate discriminant. The results of the crossloading show thatall construct correlations with the measurement items themselves have a higher value than the other construct measures, meaning that the indicator reflects the latent variables in the construct. Apart from the validity test, the outermodelalso tested the reliability. Reliability test is measured by means ofCronbach's alpha value and composite reliability. Cronbach's alpha has a standard measurement value of 0.600 while the composite reliability value must be abouve 0.700 (Ghozali, 2014). to be considered reliable. In this study, the Cronbach's alpha value and composite reliability in both normal work situations and WFH already had a Cronbach's Aplha value above 0.600 and a composite reliability value above 0.700 which can be seen in Table 2 .

\section{Structural Model ( Inner Model )}

Measurement of inner models made by looking at the value of $\mathrm{R}$ Square $\left(\mathrm{R}^{2}\right)$ to construct the dependent and the value of the $t$ statistic on the path coefficients (path coefficients) to test the significance of inter-construct the structural model. The value of $\mathrm{R}^{2}$ is used to measure the degree of variation of the change of variables independent of the variable dependent. In a normal working situation, the value of $\mathrm{R}$ square $\left(\mathrm{R}^{2}\right)$ obtained was 0.371 . This shows that the construct variables of normal work productivity can be explained by the physical and non-physical work environment variables by $37.1 \%$, while $62.9 \%$ is explained by other constructs outside the constructs examined in this study. While the WFH situation, the value of R square $\left(\mathrm{R}^{2}\right)$ obtained was 0392. This shows that the WFH work productivity construct variable can be explained by the physical and non-physical work environment variables of $39.2 \%$, while $60.8 \%$ is explained by other constructs outside the constructs examined in this study.

Furthermore, hypothesis testing is seen through the results of the path coefficients. Original sample shows the direction of the relationship between the constructs. If the value is positive it means that the constructs has a positive effect, and vice versa. The level of significance in testing the hypothesis can be seen from the t-statistics value. The influence is said to be real or significant if the value of t-statistics $>1.98$. The following is the path coefficients value of the bootsrapping result which can be seen in the Table 3. Based on table 3 , the results of hypothesis testing in the study can be explained as follows:

Table 1 Average Variance Extracted (AVE) Value in normal work situations and WFH

\begin{tabular}{lcc}
\hline Variable & AVE before dropping & AVE after dropping \\
\hline Normal Physical Work Environment & 0.426 & 0.611 \\
Normal Non Physical Work Environment & 0.513 & 0.673 \\
Normal Work Productivity & 0.570 & 0.647 \\
WFH Physical Work Environment & 0.364 & 0.630 \\
WFH Non Physical Work Environment & 0.376 & 0.911 \\
WFH Work Productivity & 0.622 & 0.668 \\
\hline
\end{tabular}

Table 2. Cronbach's alpha value and composite reliability in normal work situations and WFH

\begin{tabular}{lcc}
\hline Variable & composite reliability & cronbach's alpha \\
\hline Normal Physical Work Environment & 0.825 & 0.684 \\
Normal Non Physical Work Environment & 0.892 & 0.838 \\
Normal Work Productivity & 0.953 & 0.945 \\
WFH Physical Work Environment & 0.872 & 0.805 \\
WFH Non Physical Work Environment & 0.954 & 0.903 \\
WFH Work Productivity & 0.960 & 0.954 \\
\hline
\end{tabular}


Table 3 Path Coefficient in normal work situations and WFH

\begin{tabular}{lcccc}
\hline Relationship & $\begin{array}{c}\text { Original } \\
\text { Sample }(\mathrm{O})\end{array}$ & $\begin{array}{c}\text { T Statistics } \\
(\mid \mathrm{O} / \text { Stdev } \mid)\end{array}$ & $\begin{array}{c}\text { Standard } \\
\text { Deviation }\end{array}$ & P Value \\
\hline Normal physical work environtment $\rightarrow$ Normal work productivity & 0.227 & 2.348 & 0.097 & 0.019 \\
Normal non-physical work environtment $\rightarrow$ Normal work & 0.461 & 3.762 & 0.123 & 0.000 \\
productivity & & & & \\
WFH physical work environtment $\rightarrow$ WFH work productivity & 0.333 & 3.413 & 0.098 & 0.001 \\
WFH non-physical work environtment $\rightarrow$ WFH work productivity & 0.399 & 4.156 & 0.096 & 0.000 \\
WFH Non Physical Work Environment & 0.376 & 0.911 & & \\
WFH Work Productivity & 0.622 & 0.668 & & \\
\hline
\end{tabular}

The Effect of physical work environment towards work productivity in normal work situations.

The Effect of physical work environment towards work productivity in normal work situations is shown through the original sample which is positive $(0.227)$ indicating that the direction of the relationship between the physical work environment and the IPB's supporting staff work productivity in normal work situations is positive. Furthermore, the $p$ value $(0.019)$ which is smaller than 0.05 reflects that the physical work environment variables have a significant effect on work productivity in normal work situations. In addition, the $t$-statistic value $(2,348)$ of more than 1.98 indicates that hypothesis 1.1 is accepted. So it can be explained that the physical work environment variable has a positive relationship and has a significant effect on the work productivity of IPB's supporting staff in normal work situations. Based on this, it can be concluded that the better the physical work environment, the higher the productivity of the supporting staff.

The Effect of non-physical work environment towards work productivity in normal work situations.

The Effect of non-physical work environment towards work productivity in normal work situations is shown through the original sample which is positive $(0.461)$, indicating that the direction of the relationship of non-physical work environments and the IPB's supporting staff work productivity in normal work situations is positive. Furthermore, the $p$ value $(0.000)$ which is smaller than 0.05 reflects that the normal non-physical work environment variables have a significant effect on work productivity in normal work situations. In addition, the t-statistic value $(3,762)$ of more than 1.98 indicates that hypothesis 1.2 is accepted. So it can be explained that the non-physical work environment variable has a positive relationship and has a significant effect on the work productivity of IPB's supporting staff in normal work situations. Based on this, it can be concluded that the better the non-physical work environment is, the higher the productivity of the supporting staff.
The Effect of the physical work environment towards work productivity in the WFH situation.

The Effect of the physical work environment towards work productivity in the WFH situation is shown through the original sample which is positive (0.333) indicating that the direction of the relationship between the physical work environment and the IPB's supporting staff work productivity in WFH situations is positive. Furthermore, the $\mathrm{P}$ value $(0.001)$ which is smaller than 0.05 reflects that the WFH physical work environment variable has a significant effect on work productivity in the WFH situation. In addition, the t-statistic value $(3,413)$ of more than 1.98 indicates that hypothesis 2.1 is accepted. So it can be explained that the physical work environment variable has a positive relationship and has a significant effect on the productivity of IPB's supporting staff in the WFH situation. Based on this, it can be concluded that the better the physical work environment while working at home, the productivity of the supporting staff will also increase.

The Effect of the non-physical work environment towards work productivity in the WFH situation.

TheEffect of thenon-physical workenvironmenttowards work productivity in the WFH situation is shown through the original sample which is positive $(0.399)$ indicating that the direction of the relationship of the non-physical work environment and IPB's supporting staff work productivity in WFH situations is positive. Furthermore, the $P$ value $(0.000)$ which is smaller than 0.05 reflects that the non-physical work environment variable has a significant effect on work productivity in the WFH situation. In addition, the t-statistic value (4.156) is more than 1.98 indicating that hypothesis 2.2 is accepted. So it can be explained that the non-physical work environment variable has a positive relationship and has a significant effect on the productivity of IPB's supporting staff in the WFH situation. Based on this, it can be concluded that the better non physical work environment, the higher productivity of the supporting staff of IPB. 


\section{Managerial Implications}

Based on the research results, managerial implications were formulated with a functional management approach and adjusted to the WFH situation during the Covid-19 pandemic. The planning stage is the rationale for the goal with preparation of the steps that will be used to achieve the goals. First, in order to increase productivity during the pandemic IPB need to always maintain cleanliness and making efforts to anticipate the spread of Covid-19 within IPB. IPB can also provide personal protective equipment for supporting staff in accordance with the Covid-19 health protocol. Moreover for supporting staff who work from home during WFH, efforts to increase work productivity can be done by providing a special room for working during the WFH at home and also ensure that all supporting staff have work equipment that supports the completion of work even though they work from home IPB need o increase the productivity of the supporting staff through a non-physical work environment by forming a work policy that is adjusted to the conditions of WFH at the time of Covid-19. Supervisors can form work targets that aim to maintain the discipline of the supporting staff in achieving work standards, and do the assessment of the work productivity of the supporting staff from each division of work. The organizing stage is the stage of implementing a strategy formulated to do work effectively and efficiently in achieving goals. In a physical work environment, IPB can form different work divisions responsible for the cleanliness and safety of workplace buildings related to anticipate the spread of Covid-19. This can be done by checking the body temperature of each supporting staff before entering the workplace, scheduling disinfectant spraying on all facilities and infrastructure at IPB, allocating funds for providing PPE in accordance with the protocol. health (masks, face shields, etc.) to supporting staff which can be updated regularly. Furthermore IPB can carry out data collection on work equipment that is needed by supporting staff to support the completion of work in accordance with the main duties and functions and divisions of the supporting staff if the supporting staff have to work from home during the WFH situation.

In the non-physical work environment, IPB can regulate the work standards that supporting staff must achieve by arranging work priority points for each assigned task. Furthermore, superiors can set a schedule for assessing the work productivity of the supporting staff in each work unit or division. After the organizing stage is carried out, the next step is the implementation. This stage aims to motivate and increase the enthusiasm of all members of the work team in achieving goals in accordance with the plan. At this stage, the supervisor can hold an employee gathering to explain every detail of the work policy during WFH to all educational staff. Furthermore, giving motivation from superiors to supporting staff can be done in the form of reward and work appreciation. While working at home, IPB can also provide internet quota assistance to supporting staff and PPE in accordance with health protocols (masks, face shields, etc.). In addition, IPB can continue to provide training for educational staff by utilizing various online applications for staffeducation so that they can still improve their skills even when working from home.

Moreover the last stage is the supervision stage. This stage is the stage of periodic evaluation of the results of the directions given. Authorities such as superiors ensure that all planned activities can increase work productivity. The purpose of this stage is to find out the progress that supporting staff have achieved in achieving the planned targets beforehand so that if there is an error it can be corrected immediately so that the goal can be achieved more optimal.

\section{CONCLUSIONS AND RECOMMENDATIONS}

\section{Conclutions}

Judging from the results of the hypothesis test, it is known that the perceptions of supporting staff towards the physical and non-physical work environments at IPB are good. Meanwhile, the physical work environment during WFH according to the perceptions of the education staff is quite good and the non-physical work environment during WFH falls into the good criteria. Moreover, there was a decrease in the productivity of the supporting staff in the WFH situation caused by changes in the work environment. This shows that both in the normal work situation and in the WFH situation, the variables of the physical work environment and nonphysical work environment have a positive and significant effect on the IPB's supporting staff productivity. So that it can be concluded that the better of physical and nonphysical work environment in IPB and at home will increase the productivity of the supporting staff. The indicator of the physical work environment that most influences work productivity in normal work situations is reflected in the availability of transportation for employees. Meanwhile, in a non-physical work environment, the indicator that most influences the productivity of the supporting workforce is reflected in the communication indicator between superiors and employees who receive donation values. Unlike the 
normal work situation, in the WFH situation the indicator of the physical work environment that has the most influence on work productivity is reflected in the comfort indicator of the work building. Whereas in the non-physical work environment, job monitoring indicators during WFH have the most dominant value on the work productivity of the teaching force.

\section{Recomendations}

Based on the results, two recommendations were submitted. IPB should create a physical and non-physical work environment that is comfortable for supporting personnel and adapted to work needs in normal work situations and WFH. There is an opportunities for future research to investigate the changes of organization culture that may occur during the changes of work methods, namely Work from Home.

\section{REFERENCES}

Al-Omari K, Okasheh H. 2017. The influence of work environment on job performance: A case study of engineering company in Jordan. International Journal of Applied Engineering Research, 12(24): 15544-15550.

Amador JM. 2016. Remote and On-Site Knowledge Worker Productivity and Engagement: A Comparative Study of The Effect of Virtual Intensity and Work Location Preference. Case Western Reserve University.

Atmaja NPCD., Puspitawati, NMD. 2018. Effect of physical workenvironmentthroughproductivityemployeesjob satisfaction as an intervening variable. International Journal of Business, Economics and Law 5(17): 98104.

Bosua R, Gloet M, Kurnia S, Mandoza A, Yong J. 2013. Telework, productivity and well being. Telecommunications Journal Of Australia 63(1): 11.1-11.12

Desmonda AA. 2016. Pengaruh lingkungan kerja fisik terhadap produktivitas kerja karyawan pada pt. federal international finance cabang samarinda. $E$ Journal Administrasi Bisnis 4(4): 1179-1193

Dokery M, Bawa S. 2020. Working from Home in the COVID-19 Lockdown. Bankwest Curtin Economics Centre Research Brief COVID-19.

Ebenezer CD, Shimawua D. 2017. The effect of work environment on employee productivity: A case study of edo city transport services benin city, edo state Nigeria. International Journal of Business Innovation and Research 5(5): 23-39.
Gunaprasida N, Wibowo A. 2019. The effect of workfamily conflict and flexible work arrangement on turnover intention: do female and male employees differ?. Jurnal Siasat Bisnis 23(1): 27-36.

Ghozali I. 2014. Structural Equation Modelling Metode Alternatif dengan Partial Least Square. Semarang: Badan Penerbit Universitas Diponegoro.

Hansen R, Thordis OJ. 2017. How the Physical Work Environment Can Affect Individual Productivity. University of Stavanger

Heathfield, Susan M. 2019. The Pros and Cons of a Flexible Work Schedule. https://www.thebalancecareers.com/ [3 Mar 2020]

Joseph I. 2016. Analysis The influence of physical work environment and non-physical work environment on employee productivity in general hospital GMIM kalooran amurang south minahasa regency. Jurnal Berkala Ilmiah Efisiensi 16(4): 407-420

[Kemdikbud] Kementerian Pendidikan dan Kebudayaan. 2020. Kualifikasi dan Kompetensi Tenaga Kependidikan butuh ditingkatkan. https://pmpntb. kemdikbud.go.id. [10 Mar 2020].

[Kemdikbud] Kementerian Pendidikan dan Kebudayaan. 2020. Pengaruh Bekerja dari Rumah Terhadap Kinerja. https://ldikti13.kemdikbud.go.id. [10 Mar 2020].

[Kemdikbud] Kementerian Pendidikan dan Kebudayaan. 2020. Dinas Pendidikan diimbau Terapkan Pembelajaran Sesuai Keputusan Bersama 4 Menteri. https://kemdikbud.go.id. [10 Mar 2020].

[Kemnaker] Kementerian Ketenagakerjaan Republik Indonesia. 2020. Strategic Forum Nasional Peningkatan Produktivitas. http://produktivitas. kemnaker.go.id produktivitas/ [10 Mar 2020].

Kossek EE, Thompson RJ. 2016. Workplace Flexibility: Integrating Employer and Employee Perspectives to Close the Research Practice Implementation Gap. The Oxford Handbook of Work and Family (Oxford: OUP): 255-271.

Kramer A and Kramer KZ. 2020. The potential impact of the Covid-19 pandemic on occupational status, work from home, and occupational mobility. Journal of Vocational Behavior 103442.

Manikottama RI, Baga LM, dan Hubeis AVS. 2019. Pengaruh motivasi, lingkungan kerja dan kepemimpinan terhadap kinerja karyawan PT Satu Visi Edukasi. Jurnal Aplikasi Bisnis Dan Manajemen (JABM), 5(2), 242.-252.

Miller TM. 2016. How Telecommuters Balance Work and Their Personal Lives. Beker College.

Mustajab D et al. 2020. Fenomena bekerja dari rumah 
sebagai upaya mencegah serangan covid-19 dan dampaknya terhadap produktifitas kerja. The International Journal Of Applied Business 4(1): 1321

[PP RI] Peraturan Pemerintah Republik Indonesia. 2013.PP No. 66 Tahun 2013 tentang Statuta Institut Pertanian Bogor. Jakarta: PP Republik Indonesia.

Septiani D. 2016. Pengaruh penerapan lingkungan kerja fisik dan non fisik terhadap produktivitas kerja pegawai Kantor Camat Muara Payang Kabupaten Lahat. Jurnal Adminika 2(1): 32-42

Siddhartha V, Malika C. 2016. Telecommuting and its effects in urban planning. International Journal of Engineering Research and Technology 5(10): 44853.

Simamora H. 2004. Manajemen Sumber Daya Manusia. Yogyakarya: Sekolah Tinggi Ilmu Ekonomi YKPN.

Sondang PS. 2014. Manajemen Sumber Daya Manusia. Jakarta: PT. Bumi Aksara.

Sutrisno E. 2009. Manajemen Sumber Daya Manusia. Jakarta: Kencana

[UU RI] Undang-Undang Republik Indonesia. 2003. UU No. 20 Tahun 2003 tentang Tenaga Kependidikan. Jakarta: UU Republik Indonesia. 